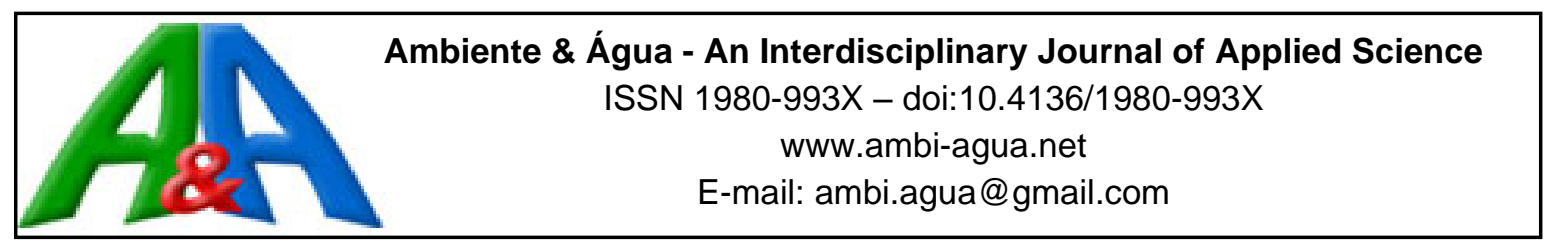

\title{
Use of natural mucilage extracted from the Stenocereus griseus (Cardón Guajiro) plant as a coagulant in the treatment of domestic wastewater
}

\author{
ARTICLES doi:10.4136/ambi-agua.2705
}

Received: 04 Feb. 2021; Accepted: 03 May 2021

\author{
Arnulfo Antonio Tarón Dunoyer ${ }^{*}{ }^{*}$; Rafael Emilio González Cuello ${ }^{1}$; \\ Fredy Colpas Castillo2
}

\footnotetext{
${ }^{\mathbf{1}}$ Faculty of Engineering. Food Engineering Program. University of Cartagena, Street 30, n48-152, 130014, Zaragocilla, Cartagena, Colombia. E-mail: rgonzalezc1@unicartagena.edu.co

${ }^{2}$ Exact and Natural Sciences Faculty. Chemistry program. University of Cartagena, Street 50, n²4120, 130014, Zaragocilla, Cartagena, Colombia. E-mail: fcolpasc1@unicartagena.edu.co

*Corresponding author. E-mail: atarond@unicartagena.edu.co
}

\begin{abstract}
Coagulants can be extracted from vegetal material and applied in the treatment of wastewater. These coagulants are derived from seeds, leaves, bark, roots and fruits. This study focuses on the use of the mucilaginous extract of Stenocereus griseus (known as Cardón Guajiro) for removal of biochemical oxygen demand ( $\left.\mathrm{BOD}_{5}\right)$, chemical oxygen demand (COD), total solids, turbidity and color in domestic wastewater from a pumping station in the city of Cartagena (Colombia). The optimal dose of $S$. griseus extract was determined by a pitcher test employing an E\&Q F6-300 digital flocculator. All physicochemical tests were carried out following the specifications of the standard methods for wastewater (APHA). When $1400 \mathrm{mgL}^{-1}$ of natural coagulants were used in the sewage treatment, the turbidity obtained was 29.57 TNU, representing removal of $67.24 \%$, considering the initial turbidity. This parameter decreases until $68.61 \mathrm{PCU}$, for a $72.12 \%$ removal at the same coagulant dosage regarding the color. It must be noted that significant statistical differences were found between all tested doses of the coagulant. The mucilaginous extract of $S$. griseus exhibited useful properties in the primary treatment of domestic wastewater.
\end{abstract}

Keywords: coagulation, color, removal, turbidity, water treatment.

\section{Tratamento primário de águas residuais domésticas a partir da mucilagem natural extraída da fábrica de Stenocereus griseus (Cardón Guajiro) como coagulante}

\section{RESUMO}

Os coagulantes podem ser extraídos de matéria vegetal e aplicados no tratamento de efluentes. Esses coagulantes são derivados de sementes, folhas, cascas, raízes e frutos. Este estudo enfoca o uso do extrato mucilaginoso de Stenocereus griseus (conhecido como Cardón Guajiro) para a remoção da demanda bioquímica de oxigênio ( $\left.\mathrm{DBO}_{5}\right)$, demanda química de oxigênio (COD), sólidos totais, turbidez e cor em águas residuais domésticas de uma estação de bombeamento na cidade de Cartagena (Colômbia). A dose ideal de extrato de S. griseus foi 
determinada por um teste de jarro empregando um floculador digital E \& Q F6-300. Todas as determinações físico-químicas foram realizadas seguindo as especificações dos métodos padrão para efluentes da APHA (Standard Methods for Water and Wastewater). Quando foram utilizados $1400 \mathrm{mgL}^{-1}$ de coagulante natural no tratamento de esgoto, a turbidez obtida foi de 29,57 TNU, representando remoção de 67,24\% considerando a turbidez inicial. Este parâmetro diminui até 68,61 PCU para uma remoção de 72,12\% na mesma dosagem de coagulante em relação à cor. Deve-se notar que diferenças estatísticas significativas foram encontradas entre todas as doses testadas do coagulante. O extrato mucilaginoso de $S$. griseus, teve propriedades valiosas no tratamento primário de águas residuais domésticas.

Palavras-chave: coagulação, cor, remoção, tratamento de água, turbidez.

\section{INTRODUCTION}

Domestic wastewater processes involve physicochemical treatment (coagulation and flocculation). Coagulation is defined as adding chemicals reagents to wastewater for agglutination of small particles into larger particles that can be removed by solids processes (Ang and Mohammad, 2020; Luo et al., 2020; Guzmán et al., 2013). A wide range of wastewater treatments has been developed over the last decades. These treatments can be classified into physical (sedimentation, filtration, adsorption and UV), chemical (coagulation, electrochemical, ion exchange, oxidation, catalytic reduction and disinfection) and biological (phytoremediation and biodegradation) (Kooijman et al., 2020; Ang and Mohammad, 2019; Hamzah et al., 2017; Kumar and Chowdhury, 2020; Hoong and Ismail, 2018).

Coagulation is an essential process for removing turbidity, color and organic matter in domestic and industrial wastewater. Some coagulants employed to remove impurities and colloidal particles from wastewater are ferric chlorides, aluminum sulfate, polyaluminum chloride, and calcium carbonate (Bergamasco et al., 2009). Nevertheless, there are some disadvantages related to the use of coagulants, such as cost, production of large volumes of sludge and $\mathrm{pH}$ modifications of the treated water (Olivero et al., 2014; Yin, 2010). Bergamasco et al., 2009). Several studies have reported the efficiency of some low-cost coagulants employed in wastewater treatments. For example, Jaafari et al. (2020) employed a magnetic chitosan to remove anionic dyes from polluted waters. Likewise, Naghipour et al. (2018) carried out studies to remove diclofenac from aqueous solutions using activated pine charcoal as adsorbent material.

Natural coagulants have been studied as an alternative to traditional chemical coagulants. Some natural coagulants studied are those obtained from vegetal species such as Moringa oleifera (Okuda et al., 1999; Caldera et al., 2007) from Cereus deficiens (commonly known as cactus or cardon lefaria) (Martínez et al., 2003) and from Opuntia cochinellifera (Almendárez de Quezada, 2004). The genus Stenocereus (Berger) Riccob Comprises a heterogeneous group of cacti distributed from southern Arizona to northern Colombia and Venezuela (Anderson, 2001; Terrazas et al., 2005). The "cardón guajiro" or "yosú" (in Wayúu language), Stenocereus griseus (Haw.) Buxb, is a columnar cactus that can reach up to $11 \mathrm{~m}$ in height. In Colombia, it is present in the departments of Guajira, Cesar and Magdalena. This vegetal species has not been studied previously as a coagulant of wastewater.

However, the active compounds of cardon guajiro, such as polysaccharides and proteins, can be a useful alternative to coagulation and flocculation processes of various pollutants. It is also a plant that grows easily on the north coast of Colombia; it has low cost and does not generate a negative environmental impact, which makes this plant a very attractive source of coagulant material for the industry. This work therefore focuses on evaluating the use of mucilage extracted from Stenocereus griseus as a natural coagulant in domestic wastewater. 


\section{MATERIALS AND METHODS}

\subsection{Wastewater sample}

The wastewater was obtained from a pumping station located in Cartagena de Indias, Colombia. The water sample was collected in the morning because, at that time, there was maximum discharge volume and the wastewater presents high levels of turbidity. The plants of S. griseus were obtained from the northern region of Colombia, at San Juan del Cesar in Guajira.

\subsection{Physicochemical characterization of wastewater.}

The wastewater sample was characterized following the Standard Methods for Water and Wastewater (APHA et al., 2012). For color determination, a colorimeter (Lovibond PFX 195) was employed using the 2120B method; the results were expressed as platinum-cobalt units (PCU). Turbidity was determined by the nephelometric method (Method 2130B) using a turbidity meter (Turbiquant $3000 \mathrm{IR}$ ). The $\mathrm{pH}$ was assessed by potentiometry with a digital potentiometer (Bench $\mathrm{pH} /$ Conductivity meter PC 510). Alkalinity was calculated by titration (expressed in $\mathrm{mg}$ of $\mathrm{CaCO}_{3} / \mathrm{L}$ ). Hardness was measured by titration using an EDTA solution as the titrating agent; this parameter was expressed in $\mathrm{mg}$ of $\mathrm{CaCO}_{3} / \mathrm{L}$. Table 1 shows the values obtained for the wastewater characterization.

Table 1. Physicochemical characterization of domestic wastewater.

\begin{tabular}{ccc}
\hline Parameters & Value & Unit \\
\hline Total alkalinity & $218.0 \pm 1.00$ & $\mathrm{mg} \mathrm{CaCO}_{3} \mathrm{~L}^{-1}$ \\
Biochemical Oxygen Demand (BOD $)$ & $128.1 \pm 0.81$ & $\mathrm{mgL}^{-1}$ \\
Chemical Oxygen Demand (COD) & $219.4 \pm 0.76$ & $\mathrm{mgL}^{-1}$ \\
Total hardness & $490.0 \pm 0.57$ & $\mathrm{mg} \mathrm{CaCO}_{3} \mathrm{~L}^{-1}$ \\
Conductivity & $1210.2 \pm 0.8$ & $\mu \mathrm{Scm}^{-1}$ \\
Turbidity & $90.28 \pm 1.00$ & $\mathrm{NTU}$ \\
Color & $246.1 \pm 0.60$ & $\mathrm{UPC}^{-1}$ \\
Total solids & $610.0 \pm 0.22$ & $\mathrm{mgL}^{-1}$ \\
\hline
\end{tabular}

\subsection{Preparation of the coagulant}

The mucilage (coagulant) was extracted from plants of $S$. griseus, especially the section between the bark and the woody tubular medulla (stem pulp). The epidermis was removed from fragments of $S$. griseus stems and the parenchymatous tissue. This parenchyma was liquefied for one (1) minute. Then, the solid phase was separated from the aqueous phase and the aqueous phase mass was determined by gravimetry. Finally, distilled water was added to obtain a mucilaginous heterogeneous mixture (Fuentes et al., 2011).

\subsection{Coagulation process}

The standard jar test described by Satterfield (2005) was used to determine the optimum coagulant dosage. The mucilaginous mixture described in Section $2.3500 \mathrm{~mL}$ of coagulantwastewater solutions at different concentrations (800, 1000, 1200, 1400 and $\left.1600 \mathrm{mg} \mathrm{L}^{-1}\right)$ was prepared employing wastewater without coagulant and another containing $\mathrm{Al}_{2}\left(\mathrm{SO}_{4}\right)_{3}$ as control. Then, both wastewaters (with and without coagulant) were subjected to agitation at $100 \mathrm{rpm}$ during 1 minute, followed by slow agitation at $40 \mathrm{rpm}$ for 30 minutes. Finally, all samples were left for 60 minutes to allow sedimentation (Tarón et al., 2017). The assays were performed at room temperature in an E\&Q F6-300 Digital Flocculator.

The turbidity removal percentage was determined using Equation 1. 
Turbidity removal $(\%)=\frac{T_{0}-T_{f}}{T_{0}} * 100$

Where: $T_{o}$ is the initial value of turbidity and $\mathrm{y} T_{\mathrm{f}}$ is the final value of turbidity.

The percentage of color removal was determined using Equation 2.

$$
\text { color removal }(\%)=\frac{C o-C f}{C o} * 100
$$

Where, $C_{o}$ is the initial value of color and $C_{f}$ is the final value of color.

\subsection{Statistical analysis}

The results were analyzed by means of ANOVA (one way) to determine statistically significant differences $(\mathrm{P}<0.05)$ among the samples. The software SPSS (Version 17.0 for Windows) was used. All tests were done in triplicate.

\section{RESULTS AND DISCUSSION}

\subsection{Physicochemical characterization of the effluent after treatment with coagulants}

Table 2 shows the physicochemical parameters evaluated in wastewater subjected to coagulant at different dosages. Statistical differences can be seen $(\mathrm{P}<0.05)$ between initial and final values of alkalinity at doses 800,100 and $1200 \mathrm{mgL}^{-1}$ of the mucilaginous extract of $S$. griseus (MES. g). These removal percentages are lower than those found for (A12(SO4)3 at all doses tested. At 1400, 1600 and $1800 \mathrm{mgL}-1$ of MES. $g$, no significant differences $(\mathrm{P}>0.05)$ were found. The results are similar to those reported by Dearmas Duarte and Ramírez Hernández (2015), that achieve efficient nutrient removal through the use of natural and chemical coagulants in a wastewater treatment plant.

As doses of MES. $g$ increase, the percentages of total solids removed also increase. The highest percentage of removal was $70.49 \%$, which was reached employing a coagulant dosage of $1400 \mathrm{mgL}^{-1}$. When high doses $\left(>1600 \mathrm{mgL}^{-1}\right)$ of coagulant were used, a slight increase in solid content was observed due to the load that can produce a re-stabilization of the system. This behavior also could be associated with the increase of coagulant requirement when the suspended solids rise, since the polymers can present an optimum coagulant concentration that depends on the molecular weight and ion concentration solids in suspension (Sánchez and Untiveros, 2004).

Regarding the chemical coagulant employed $\left(\mathrm{Al}_{2}\left(\mathrm{SO}_{4}\right)_{3}\right.$, a similar behavior was seen. However, it must be noted that solids-removal levels are higher using low doses of coagulant $\left(25 \mathrm{mgL}^{-1}\right)$. The highest percentage of solid removal was 74.95 ; this is in accordance with the observations of Dearmas Duarte and Ramírez Hernández (2015). Statistical differences were appreciated among the percentages of solids removal using different dosages of coagulant. Presently, no investigations have been conducted pertaining to the use of coagulants extracted from $S$. griseus for water purification. Nevertheless, the effect of various suspensions of Stenocereus griseus, Cereus deficiens, Opuntia ficus-indica and polyacrylamide on physical properties of the soil of Quibor (Lara State, Venezuela) has been evaluated, with Stenocereus griseus being considered the best flocculants (Henríquez et al., 2000).

The findings seen in Table 2 demonstrate that mucilaginous extract of S. griseus can be employed to decrease levels of biological and chemical degradation of organic matter. A higher percentage of chemical degradation of organic matter was reached when $1400 \mathrm{mgL}^{-1}$ of dosage of coagulant was used in the process. Statistical differences were observed among all coagulant dosages. Similar behavior was found for $\mathrm{BOD}_{5}$; the best degradation result is obtained when high doses of coagulant $\left(>1400 \mathrm{mgL}^{-1}\right)$ are used. Statistical differences were noted between all values of $\mathrm{BOD}_{5}$ obtained, as can be seen in Figure 1. 
Table 2. Physicochemical characterization of domestic wastewater using different dosages of coagulants.

\begin{tabular}{|c|c|c|c|c|c|c|c|c|}
\hline \multirow{2}{*}{ Parametros } & \multicolumn{8}{|c|}{ Dosages of mucilaginous extract of $S$. griseus $\left[\mathrm{mgL}^{-1}\right]$} \\
\hline & $C_{i}$ & 800 & 1000 & 1200 & 1400 & 1600 & 1800 & Unidades \\
\hline Total alkalinity & $218.0 \pm 1.0^{\mathrm{a}}$ & $222 \pm 05^{\mathrm{b}}$ & $230 \pm 2^{c}$ & $237 \pm 2^{\mathrm{d}}$ & $240 \pm 1^{\mathrm{d}}$ & $241 \pm 09^{d}$ & $242 \pm 2^{\mathrm{d}}$ & $\mathrm{mg} \mathrm{CaCO} \mathrm{L}^{-1}$ \\
\hline $\mathrm{BOD}_{5}$ & $128.1 \pm 0.81^{\mathrm{a}}$ & $114 \pm 02^{\mathrm{b}}$ & $102.1 \pm 08^{c}$ & $96.8 \pm 01^{\mathrm{d}}$ & $57.64 \pm 1^{\mathrm{e}}$ & $59.8 \pm 08^{\mathrm{e}}$ & $60.6 \pm 01^{\mathrm{e}}$ & $\operatorname{mgL}^{-1}$ \\
\hline COD & $219.4 \pm 0.76^{\mathrm{a}}$ & $137 \pm 07^{b}$ & $104.7 \pm 04^{c}$ & $100 \pm 09^{\mathrm{d}}$ & $70.5 \pm 03^{\mathrm{e}}$ & $82.6 \pm 1.5^{\mathrm{f}}$ & $84.2 \pm 1.3^{\mathrm{f}}$ & $\mathrm{mgL}^{-1}$ \\
\hline Total hardness & $490.0 \pm 2.5^{\mathrm{a}}$ & $450 \pm 2.1^{\mathrm{b}}$ & $445 \pm 1.1^{\mathrm{c}}$ & $409 \pm 1.5^{\mathrm{d}}$ & $400 \pm 1.0^{\mathrm{e}}$ & $402 \pm 1.9^{\mathrm{e}}$ & $406 \pm 1.8^{\mathrm{d}}$ & $\operatorname{mg~} \mathrm{CaCO}_{3} \mathrm{~L}^{-1}$ \\
\hline Conductivity & $1210.2 \pm 1.3^{\mathrm{a}}$ & $1220 \pm 1^{\mathrm{ab}}$ & $1226 \pm 1.2^{\mathrm{b}}$ & $1252 \pm 3^{c}$ & $1250 \pm 4^{c}$ & $1251 \pm 2^{c}$ & $1260 \pm 3.1^{\mathrm{d}}$ & $\mu \mathrm{Scm}^{-1}$ \\
\hline Turbidity & $90.28 \pm 1.00^{\mathrm{a}}$ & $54.7 \pm 05^{\mathrm{b}}$ & $46.66 \pm 02^{c}$ & $33.8 \pm 01^{\mathrm{d}}$ & $29.57 \pm 05^{\mathrm{e}}$ & $32.4 \pm 02^{\mathrm{e}}$ & $35.90 \pm 09^{f}$ & NTU \\
\hline Color & $246.1 \pm 1.1^{\mathrm{a}}$ & $180 \pm 1^{\mathrm{b}}$ & $115.2 \pm 2^{\mathrm{c}}$ & $80.50 \pm 2^{\mathrm{d}}$ & $68.61 \pm 09^{f}$ & $70.6 \pm 05^{\mathrm{f}}$ & $72.30 \pm 1^{\mathrm{g}}$ & UPC \\
\hline Total solids & $610.0 \pm 1.5^{\mathrm{a}}$ & $335 \pm 08^{b}$ & $261.2 \pm 01^{\mathrm{c}}$ & $219 . \pm 02^{\mathrm{d}}$ & $180.4 \pm 08^{\mathrm{e}}$ & $204 \pm 0.3^{\mathrm{f}}$ & $211,1 \pm 07^{\mathrm{f}}$ & $\mathrm{mgL}^{-1}$ \\
\hline \multicolumn{9}{|c|}{ Dosages of $\mathrm{Al}_{2}\left(\mathrm{SO}_{4}\right)_{3}\left[\mathrm{mgL}^{-1}\right]$} \\
\hline & $C_{i}$ & 10 & 15 & 20 & 25 & 30 & 35 & \\
\hline Total alkalinity & $218.0 \pm 1.0^{\mathrm{a}}$ & $219 \pm 02^{\mathrm{a}}$ & $226 \pm 1.2^{\mathrm{b}}$ & $230 \pm 2.3^{c}$ & $233 \pm 1.1^{\mathrm{c}}$ & $239 \pm 2.2^{\mathrm{d}}$ & $240 \pm 1.9^{\mathrm{d}}$ & $\mathrm{mg} \mathrm{CaCO} \mathrm{L}^{-1}$ \\
\hline $\mathrm{BOD}_{5}$ & $128.1 \pm 0.81^{\mathrm{a}}$ & $105 \pm 0.8^{\mathrm{b}}$ & $91.2 \pm 1.2^{\mathrm{c}}$ & $82.9 \pm 1.6^{\mathrm{d}}$ & $44.30 \pm 05^{\mathrm{e}}$ & $47.8 \pm 1.1^{\mathrm{f}}$ & $50.05 \pm 0.9^{f}$ & $\mathrm{mgL}^{-1}$ \\
\hline COD & $219.4 \pm 0.76^{\mathrm{a}}$ & $123 \pm 2^{b}$ & $96.5 \pm 1^{\mathrm{c}}$ & $82.4 \pm 09^{d}$ & $60.27 \pm 03^{\mathrm{e}}$ & $68.4 \pm 09^{f}$ & $70.9 \pm 1.3^{f}$ & $\mathrm{mgL}^{-1}$ \\
\hline Total hardness & $490.0 \pm 2.5^{\mathrm{a}}$ & $431 \pm 2.5^{\mathrm{b}}$ & $430 \pm 1.5^{b}$ & $394 \pm 1.1^{\mathrm{c}}$ & $381 \pm 2.1^{\mathrm{d}}$ & $383 \pm 1.9^{d}$ & $389 \pm 1.2^{\mathrm{e}}$ & $\mathrm{mg} \mathrm{CaCO} \mathrm{L}_{3} \mathrm{~L}^{-1}$ \\
\hline Conductivity & $1210.2 \pm 1.3^{\mathrm{a}}$ & $1213 \pm 4^{\mathrm{a}}$ & $1220 \pm 2.3^{\mathrm{c}}$ & $1239 \pm 2^{\mathrm{d}}$ & $1248 \pm 3.1^{\mathrm{c}}$ & $1252 \pm 1^{\mathrm{c}}$ & $1256 \pm 2.5^{\mathrm{c}}$ & $\mu \mathrm{Scm}^{-1}$ \\
\hline Turbidity & $90.28 \pm 1.0^{\mathrm{a}}$ & $42.4 \pm 09^{b}$ & $37.26 \pm 1^{\mathrm{c}}$ & $28.7 \pm 09^{d}$ & $25.67 \pm 1.2^{\mathrm{e}}$ & $26.9 \pm 1^{\mathrm{ed}}$ & $27.5 \pm 1.1^{\mathrm{d}}$ & NTU \\
\hline Color & $246.1 \pm 1.1^{\mathrm{a}}$ & $150 \pm 1.3^{\mathrm{b}}$ & $100.5 \pm 2.2^{\mathrm{c}}$ & $62.4 \pm 1.8^{\mathrm{d}}$ & $51.11 \pm 1-4^{f}$ & $55.4 \pm 09^{\mathrm{g}}$ & $59.90 \pm 1.6^{\mathrm{h}}$ & UPC \\
\hline Total solids & $610.0 \pm 1.5^{\mathrm{a}}$ & $290 \pm 2.1^{b}$ & $246.1 \pm 2.2^{c}$ & $201 . \pm 1.9^{d}$ & $152.8 \pm 1.3^{\mathrm{e}}$ & $180 \pm 1.6^{\mathrm{f}}$ & $183.4 \pm 1.9^{\mathrm{f}}$ & $\mathrm{mgL}^{-1}$ \\
\hline
\end{tabular}

*rows with different letters are significantly different ( $p<0.05$ ); mean \pm standard deviation of 3 repetitions. 


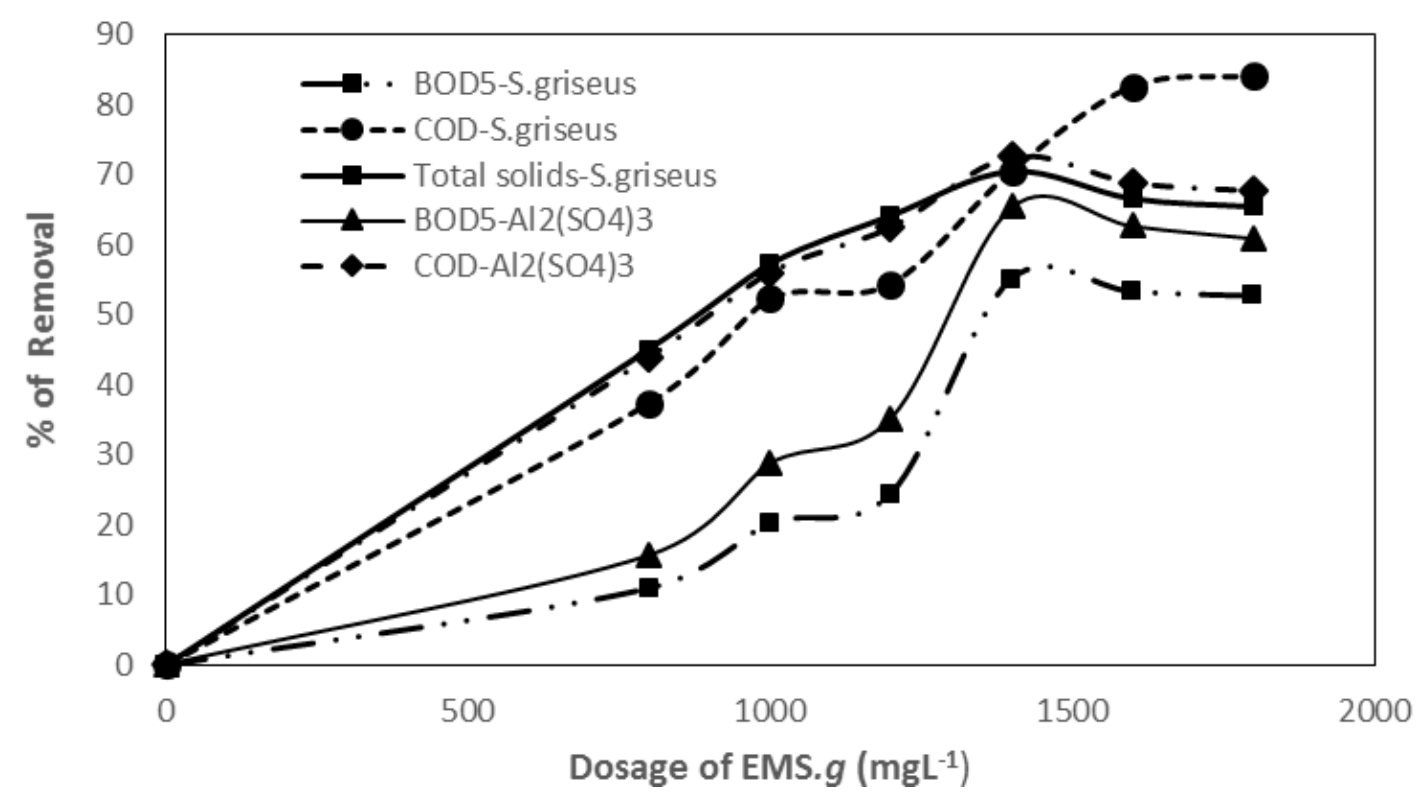

Figure 1. Removal of $\mathrm{BOD}_{5}, \mathrm{COD}$ and total solids employing mucilaginous extract of $S$. griseus and the chemical coagulant $\mathrm{Al}_{2}\left(\mathrm{SO}_{4}\right)_{3}$. *Dosages of $\mathrm{Al}_{2}\left(\mathrm{SO}_{4}\right)_{3}: 10,15,20,25,30$ and $35 \mathrm{mgL}^{-1}$.

It is observed that $\mathrm{Al}_{2}\left(\mathrm{SO}_{4}\right)_{3}$ had better results than MES. $g$. with respect to the removal of $\mathrm{COD}$ and $\mathrm{BOD}_{5}$. When $25 \mathrm{mgL}^{-1}$ of coagulant was used in the treatment, a $\mathrm{BOD}_{5}$ removal of $65.41 \%$ was reached. However, it must be highlighted that the percentage of BOD 5 removal decreased at higher dosages, likely due to system restabilization. Regarding chemical oxygen demand, a similar behavior was obtained. Its mean, the highest removal percentage was 67.86, which was significantly different from the other values obtained with various coagulants. These findings are similar to those reported by Dearmas Duarte and Ramírez Hernández (2015), who reduced wastewater BOD to $62.63 \%$.

As shown in Figure 1, chemical coagulant $\mathrm{Al}_{2}\left(\mathrm{SO}_{4}\right)_{3}$ presents better coagulation properties than natural coagulant (MES. $g$ ). It can be concluded that MES. $g$ could be an effective alternative to decrease $\mathrm{BOD}_{5}$ and $\mathrm{COD}$ values in domestic wastewater treatment; these results corroborate the studies of Tarón et al. (2017) and Guzmán et al. (2013). It is important to mention that both industrial and domestic wastewater have key characteristics regarding the composition and structure of organic matter. Hence, a better understanding of organic matter's characteristics is important to improve treatment (Liu et al., 2016).

Color and turbidity are descending functions of MES. $g$ concentration; the highest values of color and turbidity were 72.12 and $67.24 \%$, respectively. These values were obtained using a coagulant concentration of $1400 \mathrm{mgL}^{-1}$. Similar findings were published by Dearmas Duarte and Ramírez Hernández (2015). At low doses of natural coagulant, the removal of color and turbidity was not significant, possibly due to the slowness of the coagulation process, a product of the low doses (MES. $g$ ). On the contrary, the use of high doses of MES. $g$ is not adequate, since the system restabilizes and presents a stationary behavior, where there is little variation in color and turbidity removal.

In the case of $\mathrm{Al}_{2}\left(\mathrm{SO}_{4}\right)_{3}$, the higher removal percentage was obtained for both turbidity $(71.56 \%)$ and color $(79.23 \%)$; these values were obtained using a concentration of $25 \mathrm{mgL}^{-1}$ of $\mathrm{Al}_{2}\left(\mathrm{SO}_{4}\right)_{3}$. Comparing the turbidity removal percentages, significant statistical differences at $\mathrm{p}<0.05$ between the two coagulants studied were observed. These results of BOD and COD are lower than those published by Tarón et al. (2017) in aqueous extract of Cassia fistula seed in the primary treatment of domestic wastewater (Figure 2). 


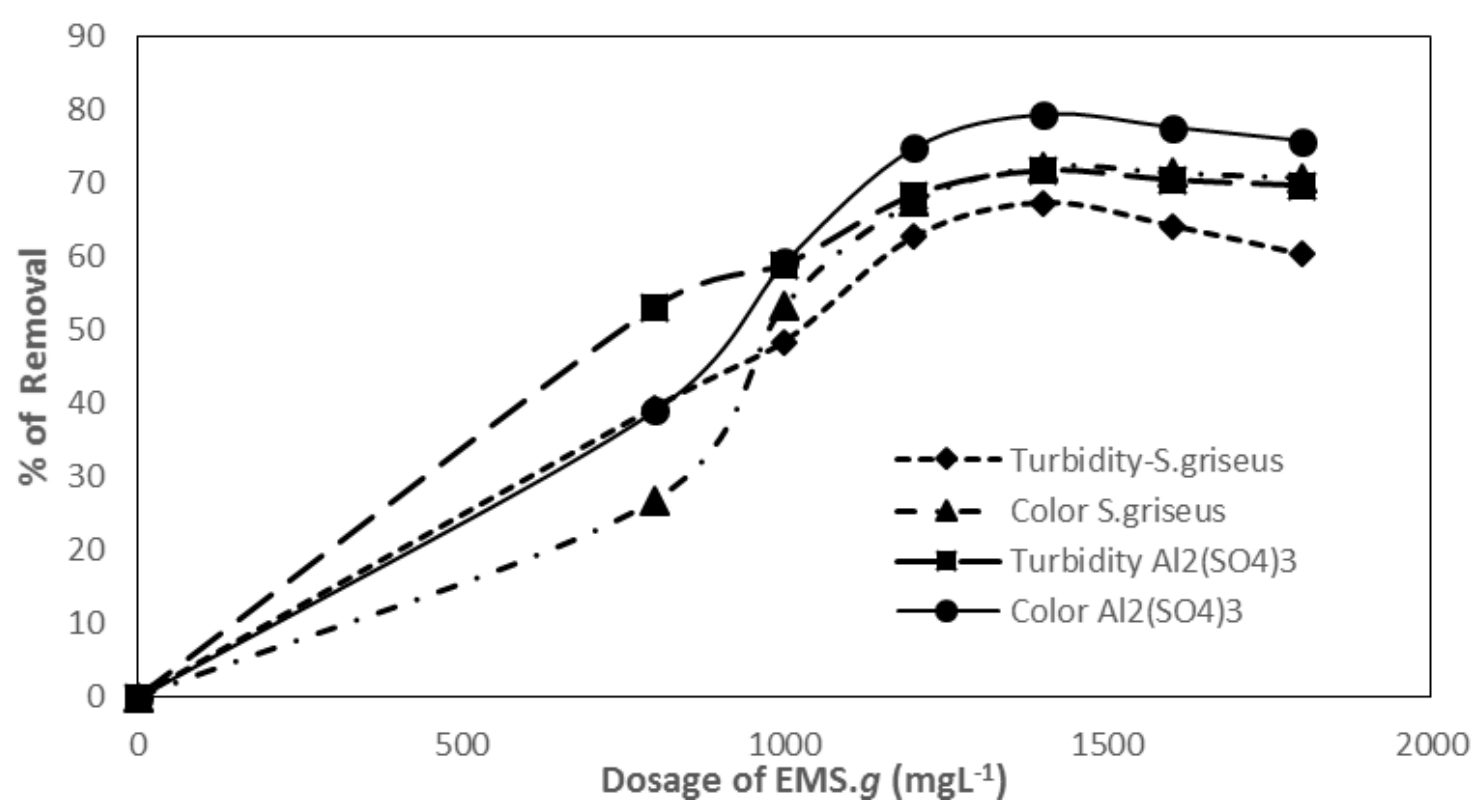

Figure 2. Turbidity and color removal using mucilaginous extract of S. griseus (MES. g) and $\mathrm{Al}_{2}\left(\mathrm{SO}_{4}\right)_{3}$. *Dosages of $\mathrm{Al}_{2}\left(\mathrm{SO}_{4}\right)_{3}: 10,15,20,25,30$ y $35 \mathrm{mgL}^{-1}$.

Although the coagulation mechanism of mucilage of S. griseus in wastewater is unknown, it is presumed that pectins (mucilage) act as coagulant-flocculants. Mucilage is a polymer with high molecular weight, which can remain long and flexible, adsorbing various particles (Sánchez and Untiveros, 2004). Likewise, Gardiner et al. (1999) indicate no clear hypothesis for the mechanism of action of cactus extracts. However, these authors suggest that the mucilage synthesized are polysaccharides structured with functional groups such as - $\mathrm{NH} 2$, $\mathrm{COOH}$ and $-\mathrm{OH}$, which leave charges that promote hydrogen bond formation.

\section{CONCLUSIONS}

The mucilaginous extract of $S$. griseus (MES. g) can be used as a coagulant in domestic wastewater treatment due to its properties to remove color, turbidity, $\mathrm{BOD}_{5}, \mathrm{COD}$ and total solids. These properties are similar to some coagulants employed in primary treatment of domestic wastewater. The percentages of removal of both turbidity and color are promising and the dosages of inorganic chemical coagulants could be reduced. The highest removal percentages $(70.42 \%$ for total solids, $72.12 \%$ color, $67.24 \%$ turbidity, $55 \%$ BOD5, and $67.86 \%$ COD) were obtained using a dosage of $1400 \mathrm{mgL}^{-1}$ of coagulant. These findings therefore could have interesting implications in the industry for the reduction of effluent contaminants.

\section{ACKNOWLEDGMENT}

The authors are especially grateful to the University of Cartagena for all their collaboration during the development of the research.

\section{REFERENCES}

ALMENDÁREZ DE QUEZADA, N. Comprobación de la efectividad del coagulante (Cochifloc) en aguas del lago de Managua Piedras Azules. Revista Iberoamericana de Polímeros, v. 5, n. 1, p. 46-54, 2004.

ANDERSON, E. The cactus family. Portland: Timber Press, 2001. 
ANG, W. L.; MOHAMMAD, A. W. Integrated and Hybrid Process Technology. Sustainable $\begin{array}{lllllll}\text { Water and Wastewater Processing, v. 9, p. 279-329, } 2019 . & \end{array}$ https://doi.org/10.1016/b978-0-12-816170-8.00009-0

ANG, W. L.; MOHAMMAD, A. W. State of the art and sustainability of natural coagulants in water and wastewater treatment. Journal of Cleaner Production, v. 262, n. 121267, 2020. https://doi.org/10.1016/j.jclepro.2020.121267

APHA; AWWA; WEF. Standard Methods for the examination of water and wastewater. 22nd ed. Washington, 2012. $1496 \mathrm{p}$.

BERGAMASCO, R.; BOUCHARD, C.; VIEIRA DA SILVA, F.; HESPANHOLD, M.; REIS, M.; FAGUNDES, M.R. An application of chitosan as a coagulant/flocculant in a microfiltration process of natural water. Desalination, v. 245, p. 205-213, 2009. https://doi.org/10.1016/j.desal.2008.04.049

CALDERA, Y.; MENDOZA, I.; BRICEÑO, L.; GARCÍA, J., FUENTES, L. Eficiencia de las semillas de Moringa oleifera como coagulante alternativo en la potabilización del agua. Boletín del Centro de Investigaciones Biológicas, v. 41, n. 2, p. 244-254, 2007.

DEARMAS DUARTE, D.; RAMÍREZ HERNÁNDEZ, L. F. Remoción de nutrientes mediante coagulantes naturales y químicos en planta de tratamiento de aguas residuales, Valledupar Colombia. Revista De Investigación Agraria Y Ambiental, v. 6, n. 2, 183-196, 2015. https://doi.org/10.22490/21456453.1415

FUENTES, L.; MENDOZA, IVÁN.; LÓPEZ, A.; CASTRO, M.; URDANETA, C. Efectividad de un coagulante extraído de Stenocereus griseus (Haw.) Buxb. en la potabilización del agua. Revista Técnica de la Facultad de Ingemiería Unividad del Zulia, v.34. n. 1, p. 39-47, 2011.

GARDINER, D.; PETER, F.; CARR, Y. Cactus extract increases water infiltration rates in two soils. Communications in Soil Science and Plant Analysis, n. 30, p. 1713-1719, 1999. https://doi.org/10.1080/00103629909370323

GUZMÁN, J.; VILLABONA, A.; TEJADA, C.; GARCÍA, R. Reduction of water turbidity using natural coagulants: a review. Revista UDCA Actualidad \& Divulgación Científica, v. 16, n. 1, p. 253-262, 2013. https://doi.org/10.31910/rudca.v16.n1.2013.881

HAMZAH, A.; MANIKAN, V.; ABD AZIZ, N.A.F. Biodegradation of tapis crude oil using consortium of bacteria and fungi: optimization of crude oil concentration and duration of incubation by response surface methodology. Sains Malaysiana, v. 46. n. 1, p. 43-50, 2017. https://doi.org/10.17576/jsm-2017-4601-06

HENRÍQUEZ, M.; MONTERO, F.; RODRÍGUEZ, O.; HERNÁNDEZ, A. Efecto de diferentes suspensiones de cardón dato, cactus lefaria, tuna española y PAM sobre algunas propiedades físicas de un suelo de Quibor-Lara. Revista de la Faculdad de Agronomia, v. 17, p. 295-306, 2000.

HOONG, H. N. J.; ISMAIL, N. Removal of dye in wastewater by adsorption coagulation combined system with Hibiscus sabdariffa as the coagulant. MATEC Web of $\begin{array}{lllllll}\text { Conferences, } & \text { v. } & 152 . & \text { n. } & 01008, & \text { p. } & 1-14,\end{array}$ https://doi.org/10.1051/matecconf/201815201008 
JAAFARI, J.; BARZANOUNI, H.; MAZLOOMI, S.; ABADI FARAHANI, N.; SHARAFI, K.; SOLEIMANI, P.; HAGHIGHAT, G. Effective adsorptive removal of reactive dyes by magnetic chitosan nanoparticles: Kinetic, isothermal studies and response surface methodology. International Journal of Biological Macromolecules, v. 164, p. 344355, 2020. https://doi.org/10.1016/j.ijbiomac.2020.07.042

KOOIJMAN, G.; DE KREUK, M. K.; HOUTMAN, C.; VAN LIER, J. B. (2020). Perspectives of coagulation/flocculation for the removal of pharmaceuticals from domestic wastewater: A critical view at experimental procedures. Journal of Water Process Engineering, v. 34, p. 101161, 2020. https://doi.org/10.1016/j.jwpe.2020.101161

KUMAR, K.; CHOWDHURY, A. Use of Novel Nanostructured Photocatalysts for the Environmental Sustainability of Wastewater Treatments, Reference Module in Mater. Encyclopedia of Renewable and Sustainable Materials, v. 1, p. 949-964, 2020. https://doi.org/10.1016/b978-0-12-803581-8.11149-x

LIU, X.; CHEN, Q.; ZHU, L. Improving biodegradation potential of domestic wastewater by manipulating the size distribution of organic matter. Journal of Environmental Sciences, v. 47, p. 174-182, 2016. https://doi.org/10.1016/j.jes.2016.02.004

LUO, X.; SHE, M.; HUANG, Z.; CHEN, Z.; CHEN, Z.; LIN, B.; CUI, L. Efficient removal of $\mathrm{Pb}$ (II) through recycled biochar-mineral composite from the coagulation sludge of swine wastewater. Environmental Research, v. 190, n. 110014, 2020. https://doi.org/10.1016/j.envres.2020.110014

MARTÍNEZ, D.; CHÁVEZ, M.; DÍAZ, A.; CHACÍN, E.; FERNÁNDEZ, N. Eficiencia del cactus lefaria para su uso como coagulante en la clarificación de las aguas. Revista Técnica de la Facultad de Ingeniería, Universidad del Zulia, v. 26. n. 1, p. 27-33, 2003.

NAGHIPOUR, D.; HOSEINZADEH, L.; TAGHAVI, T.; JAAFARI, J. Characterization, kinetic, thermodynamic and isotherm data for diclofenac removal from aqueous solution by activated carbon derived from pine tree. Data in Brief, v. 8, p. 1082-1087, 2018. https://doi.org/10.1016/j.dib.2018.03.068

OKUDA, T.; BAES, A.; NISHIJIMA, W.; OKADA, M. Improvement of extraction method of coagulation active components from Moringa oleifera seed. Water Research, v. 33, n. 15, p. 3373-3378, 1999. https://doi.org/10.1016/S0043-1354(99)00046-9

OLIVERO, R.; AGUAS, Y.; MERCADO, I.; CASAS, D.; MONTES, L. Utilización de Tuna (Opuntia ficus-indica) como coagulante natural en la clarificación de aguas crudas. AVANCES Investigación en Ingeniería, v. 11, n. 1, p. 70-76, 2014. https://doi.org/10.18041/1794-4953/avances.1.302

SÁNCHEZ, S.; UNTIVEROS, G. Determinación de la actividad floculante de la pectina en soluciones de hierro (III) y cromo (III). Revista de la Sociedad Química del Perú, v. 70. n. 4, p. 201-208, 2004.

SATTERFIELD, Z. Jar testing. Tech Brief, v. 5, n. 1, p. 1-4, 2005.

TARÓN, A.; GUZMAN, L.; PORTNOY, I. Evaluación de la Cassia fistula como coagulante natural en el tratamiento primario de aguas residuales. Revista Orinoquia, v. 21, n. 1, p. 73-78, 2017. https://doi.org/10.22579/20112629.396 
TERRAZAS, T.; LOZA, S.E.; ARREOLA, H. J. Anatomía caulinar de las especies del género Stenocereus (Cactaceae). Acta Botánica Venezuellica, v. 28. n. 2, p. 321-336, 2005.

YIN, C-Y. Emerging usage of plant-based coagulants for water and wastewater treatment. Process Biochem, v.45, https://doi.org/10.1016/j.procbio.2010.05.030 p.1437-144, 2010. 